\title{
UPAYA KEMENTERIAN AGAMA DALAM MENANGKAL RADIKALISME DI KABUPATEN GRESIK
}

\author{
Mohammad Maulana Iqbal ${ }^{1 *}$, Agus Mahfud Fauzi ${ }^{2}$ \\ ${ }^{1}$ Universitas Negeri Surabaya, INDONESIA \\ ${ }^{2}$ Universitas Negeri Surabaya, INDONESIA \\ * Correspondence: $\square$ mohammad.17040564094@mhs.unesa.ac.id
}

\begin{abstract}
Radicalism is not a new face for the Gresik people. Its existence still exists as an element that disturbs the stability of the social order in society. Therefore, we need parties who are able to ward off radicalism for the sake of balancing the social order in society. This research aims to see the various efforts made by the Ministry of Religion of Gresik Regency in counteracting radicalism. Through the perspective of the Social Action theory initiated by Max Weber, it will be seen the ratio pattern used by the Ministry of Religion of Gresik Regency in acting to fight radicalism. This study used a qualitative method by conducting direct interviews with the Ministry of Religion of Gresik Regency. The Ministry of Religion of Gresik Regency prioritizes a dialogical approach towards groups that are indicated as radical in order to instill a more moderate mindset in these groups. Based on these efforts, it can be seen that the Ministry of Religion of Gresik Regency uses the Weber Instrumental Rationality pattern in its cooperation with several parties as well as the use of Weber's Value Rationality in the orientation to be achieved in an action.
\end{abstract}

\begin{abstract}
Abstrak
Radikalisme bukanlah wajah baru bagi masyarakat Gresik, keberadaannya tetap eksis sebagai salah satu unsur yang mengganggu stabilitas tatanan sosial di masyarakat. Oleh karena itu, diperlukan pihak yang mampu menangkal radikalisme demi keseimbangan tatanan sosial di masyarakat. Penelitian ini bertujuan untuk melihat berbagai upaya yang dilakukan Kementerian Agama Kabupaten Gresik dalam menangkal radikalisme. Melalui perspektif teori Aksi Sosial yang digagas oleh Max Weber, akan terlihat pola rasio yang digunakan Kementerian Agama Kabupaten Gresik dalam bertindak untuk melawan radikalisme. Penelitian ini menggunakan metode kualitatif dengan melakukan wawancara langsung dengan Kementerian Agama Kabupaten Gresik. Kementerian Agama Kabupaten Gresik memprioritaskan pendekatan dialogis terhadap kelompok yang terindikasi radikal guna menanamkan pola pikir yang lebih moderat pada kelompok tersebut. Berdasarkan beberapa upaya tersebut, terlihat bahwa Kementerian Agama Kabupaten Gresik menggunakan pola Rasionalitas Instrumental Weber dalam kerjasamanya pada beberapa pihak serta penggunaan Rasionalitas Nilai Weber dalam orientasi yang ingin dicapai dalam suatu tindakan.
\end{abstract}

\section{Article History}

Received: 23-12-2020,

Revised: 31-12-2020,

Accepted: $31-12-2020$

Keywords:

Ministry of Religion;

Radicalism

Social Action;
Histori Artikel

Diterima: 23 -12 -2020

Direvisi: $31-12-2020$

Disetujui: $31-12-2020$

Kata Kunci:

Radikalisme;

Kementerian Agama;

Tindakan Sosial;

(C) 2020 Mohammad Maulana Iqbal, Agus Mahfud Fauzi

This work is licensed under a Creative Commons Attribution-ShareAlike 4.0 International License.

\section{A. Pendahuluan}

Radikalisme bukanlah fenomena yang baru bagi telinga masyarakat Indonesia. Sudah cukup lama radikalisme sudah menemani kehidupan tatanan sosial di masyarakat. Bibit-bibit yang terindikasi radikalisme sebetulnya sudah ditemui semenjak pasca kemerdekaan Indonesia melalui gerakan-gerakan yang mengatasnamakan agama demi tujuan pendirian negara berasaskan agama 
tertentu dengan cara yang instan. Namun gerakan radikal mulai fenomenal ditengah masyarakat ketika mulai gencarnya gerakan teror yang mengusik ketentraman equilibrium tatanan sosial. ${ }^{1}$ Lebih tepatnya era jatuhnya Soeharto dimana reformasi digelontarkan, demokratisasi disebarkan, kebebasan berekspresi dilegalkan. ${ }^{2}$ Dalih kebebasan berekspresi, berpendapat, demokratisasi menjadi peluang bagi gerakan radikal untuk semakin menunjukkan eksistensinya di masyarakat. Mereka semakin leluasa untuk memperlihatkan jati diri mereka kepada khalayak umum.

Gerakan radikal menjadi makin mengkhawatirkan ketika mereka mulai melakukan pemboman di tempat-tempat umum. Sehingga beberapa aksi mereka dapat mengancam jiwa setiap warga Indonesia. Dapat dilihat dalam gerakan Komandan Jihad (Komji) yang meledakkan tempat peribadatan pada tahun 1976. Ditambah pasca reformasi juga ditemui beberapa gerakan berbau radikalisme yang dipimpin oleh Azhari dan Nurdin M. Top. ${ }^{3}$ Selain itu masih banyak lagi gerakangerakan radikalisme di Indonesia yang cukup mengganggu ketentraman masyarakat. Masyarakat menjadi khawatir, tatanan sosial akan terusik, dan stabilitas kehidupan masyarakat akan terganggu dengan kehadiran kelompok radikalisme di tengah masyarakat.

Gerakan radikal tidak selalu berkutat pada pemboman, terorisme maupun tindakan-tindakan kekerasan lainnya yang mencoreng nilai-nilai kemanusiaan. Selain gerakan kekerasan, melalui gerakan kecil yang cukup mengganggu ketentraman masyarakat dapat menjadi bibit yang terindikasi radikalisme. Salah satu contoh yang dapat dilihat yakni Majelis Tafsir Al-Qur'an (MTA) yang memiliki cabang di Gresik. MTA ada sebuah organisasi yang didirikan oleh Abduallah Thufail Saputra di Surakarta, tepatnya 19 September $1972 .{ }^{4}$ Organisasi ini mengemban semangat pemurnian atau kembali pada Al Qur'an dan Hadits, sehingga segala tindakan yang dianggap Bid'ah, Tahayyul dan Khurafat akan ditolak oleh mereka. ${ }^{5}$ Berbagai tindakan MTA tersebut juga ditemui di kecamatan Kebomas, Gresik, melalui cabangnya yang berada di Gresik. Salah satu tindakan MTA yakni menganggap Bid'ah beberapa kegiatan upacara pemakaman warga setempat. ${ }^{6}$ Atas tindakan yang dilakukan oleh anggota MTA tersebut, warga setempat merasa terganggu akan kehadiran MTA di lingkungan mereka. Bahkan lebih dari pada itu, MTA dianggap sebagai aliran sesat dan juga sangat berpotensi menimbulkan konflik di masyarakat seperti halnya di wilayah lain. $^{7}$

Berdasarkan munculnya gerakan-gerakan radikal yang berpotensi menimbulkan keresahan di masyarakat, maka sangat diperlukan pihak-pihak tertentu yang dapat menyelesaikan gesekangesekan konflik di masyarakat tersebut. Terutama masyarakat Gresik yang dihadiri oleh gerakangerakan radikal, salah satunya seperti MTA. Lebih penting lagi ketika pihak-pihak pemerintah Gresik ikut andil dalam penyelesaian konflik di masyarakat. Sebab, pihak pemerintah memiliki kewajiban untuk menjaga stabilitas sosial yang ada di masyarakat. Pihak pemerintah memiliki tugas untuk menjaga keharmonisan masyarakat dalam beragama. Konflik-konflik agama amat harus dapat terselesaikan oleh pihak pemerintah. Terutama pihak pemerintah Gresik yang menangani konflik keagamaan seperti Kementerian Agama Kabupaten Gresik.

\footnotetext{
${ }^{1}$ Stefan Malthaner, "Radicalization: The Evolution of an Analytical Paradigm," Archives Europeennes de Sociologie 58, no. 3 (2017): 392, https://doi.org/10.1017/S0003975617000182.

${ }^{2}$ Ahmad Asrori, "Radikalisme Di Indonesia : Antara Historisitas Dan Antropisitas" 9 (n.d.): 256.

${ }^{3}$ Asrori, 256.

${ }^{4}$ Muhammad Romdloni Putra, "Islam Lokas Vis A Vis Islam Puritan (Studi Kasus Konflik Antara Majelis Tafsir Al-Qur'an Dan Nahdlatul Ulama Di Kabupaten Gresik)” (Universitas Islam Negeri Sunan Ampel, 2018 ), 99.

${ }^{5}$ Putra, 100.

${ }^{6}$ Mohammad Ridwan, "Warga Kebomas Gresik Resahkan Pengajian MTA,” lensaindonesia.com, 2012, https://www.lensaindonesia.com/2012/12/06/warga-kebomas-gresik-resahkan-pengajian-mta.html.

${ }^{7}$ Endang Sukarelawati, "Pemkab Gresik Hentikan Kegiatan MTA," jatim.antaranews.com, 2014, https://jatim.antaranews.com/berita/125601/pemkab-gresik-hentikan-kegiatan-mta.
} 
Kementerian Agama Kabupaten Gresik merupakan elemen pemerintah yang menangani berbagai hal yang berhubungan dengan agama. Salah satunya yakni menjamin kesejahteraan masyarakat Gresik dalam beragama. Terlebih meminimalisir, mencegah, bahkan meniadakan gerakan-gerakan berbau radikalisme di Gresik. Hal ini juga telah tertuang dalam visi Kementerian Agama Kabupaten Gresik yakni "Terwujudnya masyarakat Gresik yang taat beragama, Inklusif, toleran, Rukun, Berpendidikan, Mandiri, Sejahtera lahir batin." ${ }^{8}$ Oleh karena itu, di dalam artikel ini berusaha memaparkan peran Kementerian Agama Kabupaten Gresik dalam menangkal radikalisme yang ada di masyarakat Gresik. Artikel ini akan melihat langkah-langkah yang dilakukan oleh Kementerian Agama Kabupaten Gresik dalam menangani radikalisme di kabupaten Gresik.

Selain itu, perlu diketahui juga bahwa penelitian perihal peran pemerintah dalam menangani radikalisme bukanlah penelitian yang baru. Terdapat penelitian lainnya yang secara konsepsi general memiliki kesamaan tema berdasarkan perspektif dan konteksnya masing-masing. Layaknya penelitian yang dilakukan oleh Windy Sapta Ningsih. Ia mengungkapkan bahwa terdapat beberapa peran KUA (Kantor Urusan Agama) Kecamatan Metro Kibang Lampung Timur dalam pencegahan radikalisme seperti menekankan kepada para penyuluh agar menjalankan SOP yang telah ditetapkan, peningkatan sumber daya manusia melalui keikutsertaan dalam berbagai pelatihan, penekanan penguasaan pada penyuluh agama tentang materi pencegahan radikalisme, peningkatan sarana dan prasarana IT agar dapat mengakses informasi terkait isu radikalisme. ${ }^{9}$

Selain itu, hal serupa juga dilakukan oleh Muhamad Umar Fauzi. Beliau menuturkan bahwa terdapat beberapa strategi yang dilakukan penyuluh agama Islam di kabupaten Nganjuk, diantaranya seperti menempatkan penyuluh agama Islam yang berkopetensi dalam bidang radikalisme di setiap kecamatan, melakukan audiensi pada pihak berwenang dalam mengentas radikalisme, menggali informasi sekaligus melakukan sosialisasi kepada masyarakat perihal bahayanya paham radikalisme, melakukan pemetaan pada kelompok yang terindikasi radikalisme, menguatkan akidah dan rasa nasionalisme kepada setiap masyarakat. ${ }^{10}$

Beberapa riset sebelumnya memperlihatkan bagaimana peran pemerintah, terutama KUA melalui penyuluh agama melakukan berbagai upaya untuk mencegah maupun memberantas fenomena radikalisme. Keduanya berfokus pada penyuluh agama yang memiliki peran penting dalam penangkalan radikalisme. Terutama penyuluh agama yang bertempat di setiap kecamatan. Sedangkan artikel ini lebih fokus pada kebijakan Kementerian Agama kabupaten Gresik dalam menangani fenomena radikalisme di masyarakat. Perbedaan strata pemerintahan dan perbedaan konteks masyarakat yang terjadi maka dapat memunculkan peranan yang berbeda pula dalam menangkal radikalisme sesuai dengan konteks yang terjadi.

\section{B. Kajian Pustaka}

\section{Radikalisme}

Terdapat berbagai pendapat mengenai konsepsi dari radikalisme. Jika ditinjau dari sisi kebahasaan, maka radikal berasal dari bahasa latin yakni "Radix" yang memiliki arti akar, pangkal,

\footnotetext{
${ }^{8}$ Fudlla, Profil Kantor Kementerian Agama Kabupaten Gresik Tahun 2019 (Gresik: Humas Kantor Kementerian Agama Gresik, 2019).

${ }^{9}$ Windy Sapta Ningsih, "Peran Penyuluh Agama Dalam Mengantisipasi Aliran Radikal (Studi Kasus KUA Kecamatan Metro Kibang Lampung Timur)" (INSTITUT AGAMA ISLAM NEGERI METRO, 2019).

${ }^{10}$ Muhamad Umar Fauzi, "Strategi Penyuluh Agama Islam Dalam Menangkal Faham Radikalisme Di Kabupaten Nganjuk Muhamad Umar Fauzi,” At-Tahdzib: Jurnal Studi Islam Dan Muamalah 6, no. 1 (2018): 17-49.
} 
permukaan bawah. ${ }^{11}$ Melalui asal usul kebahasaan ini amat kurang lengkap jika tidak diiringin oleh definisi secara istilah dari radikalisme itu sendiri. Definisi secara istilah dapat ditemui salah satunya yakni yang diungkapkan oleh masduqi, ia menyebutkan bahwa radikalisme sebagai sebuah prilaku fanatis terhadap suatu konsepsi tertentu yang dimiliki oleh individu maupun kelompok dan memiliki kecenderungan untuk menolak berbagai konsepsi diluar apa yang diyakininya. ${ }^{12}$ Sehingga dapat dikatakan bahwa radikalisme merupakan sebuah keteguhan yang dipegang oleh individu atau kelompok terhadap apa yang mereka yakini. Mereka sangat percaya dengan yakin perihal berbagai konsepsi agama yang diyakininya. ${ }^{13}$ Keteguhan terhadap apa yang diyakini inilah yang dapat berpotensi pada sebuah prilaku penolakan, menyalahkan konsepsi lain, bahkan menstigmatisasi "kafir" individu lain. Oleh karena itu, dalam konsepsi radikalisme memiliki dua term yang saling terkait didalamnya. Kedua term tersebut yakni sebuah prilaku fanatisme terhadap konsepsi yang diyakini dan prilaku penolakan atau menyalahkan konsepsi lain yang bertolak belakang dengan konsepsi yang diyakini.

\section{Tindakan Sosial Max Weber}

Berbagai tindakan yang telah dilakukan Kementerian Agama kabupaten gresik dalam upayanya menangkal radikalisme di kabupaten Gresik. Berbagai tindakan yang telah dilakukan tersebut dapat di analisis melalui pondasi teori Tindakan Sosial yang dikemukakan oleh Max Weber. Sehingga melalui pondasi teori tersebut maka segala tindakan yang dilakukan oleh Kementerian Agama Kabupaten Gresik dalam menangkal radikalisme akan dikategorisasi melalui empat proporsi yang dimiliki dalam teori Tindakan Sosial Max Weber.

Keempat proporsi yang dimiliki teori Tindakan Sosial tersebut yakni sebagai berikut; ${ }^{14}$ Pertama, Tindakan Rasionalitas Instrumental. Konsep ini sebagai suatu tindakan secara sadar guna mencapai suatu tujuan tertentu melalui alat yang dianggap efektif dan juga tentu telah tersedia sebelumnya. Sehingga tindakan pencapaian dalam suatu tujuan tersebut atas dasar alat yang digunakannya. Kedua, Rasionalitas Nilai. Tindakan ini lebih berorientasi pada tujuan yang ingin dicapai. Tujuan yang ingin dicapai yakni berupa suatu nilai tertentu maupun suatu manfaat tertentu dalam tatanan sosial masyarakat. Ketiga, Tindakan Afeksi. Tindakan ini lebih berlandaskan pada perasaan emosional tertentu tanpa landasan kesadaran secara rasional dalam bertindak. Keempat, Tindakan Tradisional. Tindakan ini merupakan sebuah tindakan yang dilandaskan oleh sebuah konsensus rutinitas yang telah membudaya di masyarakat. Lebih dari pada itu, rutinitas tersebut diperoleh secara turun temurun dari generasi ke generasi. Bahkan telah menjadi sebuah kultur tertentu di masyarakat.

\section{Metode Penelitian}

Secara konseptual dalam metode penelitian lapangan, maka model penelitian terbagi menjadi dua model. Kedua model tersebut diantaranya yakni metode kualitatif dan metode kuantitatif. Kedua metode ini memiliki konsep metode, analisis maupun penyajian data yang berbeda-beda sesuai dengan ciri khasnya masing-masing. Namun, dalam penelitian ini hanya akan menggunakan satu metode saja yaitu metode kualitatif. Alasannya dikarenakan di dalam penelitian ini berusaha menggali fenomena penanganan Kementerian Agama Kabupaten Gresik dalam menangkal

\footnotetext{
${ }^{11}$ Fauzi, 29.

${ }^{12}$ Peyman Hekmatpour, "What Do We Know about the Islamic Radicalism : A Meta-Analysis of Academic What Do We Know about the Islamic Radicalism : A Meta-Analysis of Academic Publications," no. January 2018 (2019): 5.

${ }^{13}$ A Faiz Yunus, "Radikalisme, Liberalisme Dan Terorisme: Pengaruhnya Terhadap Agama Islam," Jurnal Online Studi Al-Qur An 13, no. 1 (2017): 80, https://doi.org/10.21009/jsq.013.1.06.

${ }^{14}$ Bryan S. Turner, Teori Sosial Dari Klasik Sampai Postmodern (Yogyakarta: Pustaka Pelajar, 2012), 115.
} 
radikalisme secara kompleks. Melalui metode kualitatif akan ditemui realitas yang terjadi dalam penanganan radikalisme di Gresik. Hal ini sesuai dengan tipikal penelitian menggunakan metode kualitatif. Sedangkan, metode kualitatif sendiri jika secara fundamental dapat dikatakan sebagai metode penelitian yang menitik fokuskan pada pendiskripsian dan analisis berdasarkan fenomena sosial yang terjadi, baik secara individu maupun secara kolektif. Sehingga pada aspek penyajian data dalam penelitian kualitatif tidak akan ditampilkan dalam bentuk nomerik statistik, melainkan dalam wujud pemaparan penjelasan deskriptif dan gambaran perwujudan atas fenomena yang terjadi. ${ }^{15}$ Oleh sebab itu, hasil yang didapatkan dari penelitiannya akan berupa intrepetasi atas suatu fenomena dengan penyajian deskriptif.

Adapun penelitian ini menggunakan beberapa langkah teknik pengumpulan data untuk mendapatkan data secara kompleks. Jika ditinjau dari metode kualitatif yang digunakan, maka dapat dilakukan secara observasi wawancara, analisis dokumen, maupun dengan diskusi terfokus. ${ }^{16}$ Secara struktural defitinif, teknik pengumpulan data tersebut dapat dilihat sebagai berikut; Pertama yaitu observasi, merupakan sebuah bentuk metode pengumpulan data dengan cara mengamati berbagai fenomena disekitar pusat penelitian dilapangan. Langkah ini merupakan langkah awal untuk mengetahui informasi dasar mengenai topik penelitian yang diambil. Kedua yaitu wawancara, merupakan sebuah metode pengumpulan data yang dengan cara pertemuan anatara peneliti dengan informan yang ingin digali informasinya dengan melakukan sebuah sesi tanya jawab, sehingga dari tanya jawab ini dibangun suatu makna dalam suatu topik tertentu. Dan yang terakhir yaitu dokumentasi, merupakan sebuah cara untuk mengumpulkan sekaligus menganalisis dokumendokumen dari penelitian yang telah dilakukan, baik berupa dokumen tertulis, gambar, maupun rekaman

Lokasi penelitian ini berlokasikan di kabupaten Gresik. Gresik selain memiliki julukan sebagai kota santri selain Jombang yang terkenal akan relegiusitasnya, disisi lain Gresik juga terdapat fenomena gerakan radikalisme seperti MTA. Oleh karena itu, penelitian ini dikalukan di kabupaten Gresik. Lebih fokusnya lagi, penelitian ini dilakukan di Kantor Kementerian Agama Kabupaten Gresik yang bertempat di Jl. Jaksa Agung Suprapto. No. 39, Sumursango, Bedilan, Kec. Gresik, Kab. Gresik, Jawa Timur. Alasan utama menitik fokuskan penelitian ini pada Kementerian Agama Kabupaten Gresik ialah dikarenakan Kementerian Agama merupakan lembaga pemerintah di bidang keagaamaan yang juga menangani fenomena radikalisme di masyarakat. Lebih dari pada itu, subyek dalam penelitian ini yakni staf dari Kantor Kementerian Agama Kabupaten Gresik itu sendiri. Melalui penelitian di Kantor Kementerian Agama Kabupaten Gresik ini akan memperlihatkan berbagai peran Kemenag dalam menangkal berbagai problem radikalisme di masyarakat.

\section{Pembahasan atau Analisis}

\section{Radikalisme dari Kacamata Kementerian Agama}

Sebelum jauh mengulas upaya-upaya yang dilakukan oleh Kementerian Agama Kabupaten Gresik dalam menangkal radikalisme di Gresik, maka amat perlu dipahami terlebih dahulu mengenai konsepsi radikalisme itu sendiri menurut Kementerian Agama Kabupaten Gresik. Berdasarkan hasil penelitian yang telah dilakukan, ditemukan beberapa konsepsi maupun substansi secara definitif mengenai radikalisme menurut Kementerian Agama Kabupaten Gresik. Konsepsi

\footnotetext{
${ }^{15}$ Burhan Bungin, Metodologi Penelitian: Format-Format Kuantitatif Dan Kualitatif (Surabaya: Airlangga University Press, 2005), 103.

${ }^{16}$ Sandu \& Ali Sodik Siyoto, Dasar Metodologi Penelitian (Yogyakarta: Literasi Media Publishing, 2015$), 68$.
} 
tersebut ditemukan melalui wawancara secara langsung kepada H. Munir, M.Ag selaku Kasubag TU Kantor Kementerian Agama Kabupaten Gresik.

Terdapat beberapa konsepsi mengenai radikalisme menurut Kementerian Agama Kabupaten Gresik. Jika ditinjau dari aspek kebahasaannya, maka radikalisme berasal dari kata "Radix" yang memiliki arti akar. ${ }^{17}$ Begitupun yang diungkapkan juga oleh Fauzi bahwa radikal berasal dari bahasa latin yakni "Radix" yang memiliki arti akar, pangkal, permukaan bawah. ${ }^{18}$ Sedangkan jika ditinjau dari segi definisinya maka yang dikatakan radikal adalah sebuah pola berfikir yang sangat kuat, idealis, komitmen terhadap apa yang diyakini. Berdasarkan konsepsi tersebut, maka dapat dikatakan bahwa mereka yang berprinsip radikal cukup dapat dikatakan baik atau bagus diterapkan dalam diri setiap individu. Sebab, jika individu berkomitmen pada apa yang diyakininya maka individu tersebut akan melakoni kehidupan secara Istiqomah, integritas, berpendirian kuat. ${ }^{19}$

Namun, prilaku radikal jatuh pada sebuah tindakan yang dikatakan "salah" ketika seorang individu radikal telah jatuh pada fanatisme secara buta. Individu tersebut telah jatuh pada pembenaran secara buta pada pendapatnya sendiri. Sehingga implikasi yang ditimbulkan adalah prilaku yang menolak secara mentah, bahkan menyalahkan berbagai konsepsi diluar apa yang diyakininya. ${ }^{20}$ Konsepsi tersebut juga disepakati oleh masduqi bahwa radikalisme sebagai sebuah prilaku fanatis terhadap suatu konsepsi tertentu yang dimiliki oleh individu maupun kelompok dan memiliki kecenderungan untuk menolak berbagai konsepsi diluar apa yang diyakininya. ${ }^{21}$ Dititik inilah radikal telah menjadi elemen yang dapat mengganggu stabilitas yang ada dalam tatanan sosial masyarakat. Oleh karena itu, radikalisme pada fase ini dilarang bahkan diberantas oleh Kementerian Agama Kabupaten Gresik.

Radikal jika hanya sebatas internal dalam diri sendiri dan tidak sampai dieksplorasi pada prilaku menyalah-nyalahkan pendapat atau konsepsi orang lain maka tidaklah menjadi masalah. ${ }^{22}$ Sebab ketika masih dalam internal diri individu maka berdampak postif sebagai sebuah komitmen diri pada apa yang diyakini. Namun, ketika telah dieksplorasikan maka dapat berpotensi pada terusiknya equilibrium dalam tatanan sosial di masyarakat. Tentunya hal tersebut tidak diinginkan oleh Kementerian Agama Kabupaten Gresik.

Melalui berbagai konsepsi tersebut dapat dikatakan bahwa Kementerian Agama Kabupaten Gresik membagi menjadi dua karakteristik radikalisme. Pertama, radikal dalam artian komitmen individu terhadap apa yang diyakininya dalam diri sendiri. Prilaku ini tidak dilarang oleh Kementerian Agama Kabupaten Gresik, bahkan dianggap baik karena dapat memunculkan berbagai nilai positif seperti Istiqomah, teguh pendirian dan lain-lain. Kedua, radikal dalam artian fanatisme secara buta terhadap apa yang diyakini sekaligus menolak bahkan menyalahkan berbagai konsepsi diluar diri individu. Radikal yang seperti inilah yang dilarang oleh Kementerian Agama Kabupaten Gresik. Sebab melalui tindakan radikal seperti ini dapat mengganggu ketentraman dalam tatanan sosial masyarakat, lebih khususnya masyarakat kabupaten Gresik.

Oleh karena itu, indikator utama yang dipegang oleh Kementerian Agama Kabupaten Gresik dalam menangkal radikalisme yakni pada aspe fanatisme secara buta yang dimiliki seseorang maupun kelompok. Prilaku yang gemar menyalahkan, membid'ahkan, mengkafirkan pihak lain

\footnotetext{
${ }^{17}$ Munir, "Hasil Wawancara Dengan Kepala Sub Bagian Tata Usaha Kementerian Agama Kabupaten Gresik” (Gresik, 2020).

${ }^{18}$ Fauzi, "Strategi Penyuluh Agama Islam Dalam Menangkal Faham Radikalisme Di Kabupaten Nganjuk Muhamad Umar Fauzi," 29.

${ }^{19}$ Munir, "Hasil Wawancara Dengan Kepala Sub Bagian Tata Usaha Kementerian Agama Kabupaten Gresik."

${ }^{20}$ Munir.

${ }^{21}$ Irwan Masduqi, BerIslam Secara Toleran: Teologi Kerukunan Umat Beragama (Bandung: Mizan, 2012$), 116$.

${ }^{22}$ Munir, "Hasil Wawancara Dengan Kepala Sub Bagian Tata Usaha Kementerian Agama Kabupaten Gresik."
} 
inilah yang menjadi sorotan Kementerian Agama Kabupaten Gresik. Disisi lain, pakaian belum tentu mengindikasikan individu atau kelompok dapat dikatakan sebagai radikal. Sebab, Kementerian Agama Kabupaten Gresik sering berkomunikasi dengan kelompok yang sering distigmatisasi radikal oleh masyarakat seperti cadar atau celana cingkrang yang justru tidak ditemukan indikasi radikalisme pada mereka. Sehingga pakaian tidak dapat menjadi indikator dari radikalisme sebab hal tersebut hanyalah bersifat permukaan eksistensial belaka. Justru radikalisme harus dipandang dari aspek yang lebih esensial, substantif, seperti pola berfikir maupun bertindak.

\section{Wajah Radikalisme di Gresik}

Gresik merupakan satu diantara berbagai daerah di Indonesia yang memiliki julukan mengenai prilaku relegiusitas yang dimiliki masyarakatnya. Salah satunya yakni Gresik dijuluki sebagai "kota santri". Hal tersebut juga ditegaskan oleh Munir selaku Kasubag Kemenag Gresik, bahwa Gresik merupakan wilayahnya para santri. ${ }^{23}$ Julukan Gresik sebagai kota santri juga dapat ditunjukkan dalam jumlah pondok pesantren di Gresik yang mencapai kurang lebih 149 pondok pesantren yang menyebar diseluruh wilayah di Gresik. ${ }^{24}$ Dapat dikatakan jumlah yang cukup banyak, sehingga tidak mengherankan julukan "kota santri" melekat di kabupaten Gresik.

Lebih dari pada itu, kabupaten Gresik juga terkenal dengan daerah yang memiliki dua makam wali sekaligus dari sembilan wali yang populer di Jawa. Kedua wali tersebut yakni Sunan Gresik (Maulana Malik Ibrahim) dan Sunan Giri (Raden Paku). ${ }^{25}$ Terlebih, Sunan Gresik juga merupakan Sunan senior dari kesembilan wali yang populer di Jawa. ${ }^{26}$ Melihat penyebaran nilai-nilai agama yang begitu kental tersebut maka tidak mengerankan jika Gresik sebagai wilayah yang agamis, memiliki keimanan yang tinggi dan juga penuh dengan jejak dakwah ajaran para wali. ${ }^{27}$

Namun, berdasarkan berbagai realita agama yang amat begitu melekat di masyarakat Gresik tersebut tidak memungkiri juga bahwa stabilitas tatanan sosial tidak dapat terganggu oleh radikalisme. Kentalnya relegiusitas masyarakat Gresik juga tidak menjamin terbebasnya gerakan radikal yang mengatasnamakan agama. Justru gerakan radikal dapat muncul diberbagai tipikal masyarakat yang dihadapinya tanpa memandang latar belakang yang dimiliki suatu masyarakat.

Salah satunya gerakan radikalisme yang ditemui di kabupaten Gresik yakni yakni Majelis Tafsir Al-Qur'an (MTA). Organisasi ini didirikan di Surakarta tepat pada tanggal 19 September 1972 oleh Abdullah Thufail Saputra. ${ }^{28}$ Organisasi ini juga memiliki upaya untuk pemurnian atau kembali pada Al Qur'an dan Hadist atas segala kehidupan masyarakat, sehingga berbagai tindakan yang dianggap sebagai tindakan yang Bid'ah, Tahayyul dan Khurafat maka akan ditolak secara penuh oleh organisasi ini. ${ }^{29}$ Begitupun yang terjadi di kecamatan Kebomas, kabupaten Gresik. MTA di cabang Gresik menganggap Bid'ad beberapa kegiatan upacara pemakanan yang dilakukan oleh masyarakat setempat. ${ }^{30}$ Tindakan penolakan yang dilakukan MTA tersebut juga sebagai bentuk

\footnotetext{
${ }^{23}$ Munir.

${ }^{24}$ Fudlla, Kementerian Agama Kabupaten Gresik Dalam Angka 2019 (Gresik: Humas Kantor Kementerian Agama Gresik, 2019).

${ }^{25}$ Fajria Aninda Utami, “Makam Sunan Giri Dan Sunan Gresik Sebagai Wisata Religi,” Umroh.com, 2020, https://umroh.com/blog/makam-sunan-giri-dan-sunan-gresik-di-gresik/.

${ }^{26}$ Ari Welianto, "Sunan Gresik, Wali Pertama Penyebar Islam Di Tanah Jawa,” KOMPAS.com, 2020, https://www.kompas.com/skola/read/2020/02/22/120000769/sunan-gresik-wali-pertama-penyebar-islam-di-tanahjawa?page=all.

${ }^{27}$ Munir, "Hasil Wawancara Dengan Kepala Sub Bagian Tata Usaha Kementerian Agama Kabupaten Gresik."

${ }^{28}$ Putra, "Islam Lokas Vis A Vis Islam Puritan (Studi Kasus Konflik Antara Majelis Tafsir Al-Qur'an Dan Nahdlatul Ulama Di Kabupaten Gresik)," 99.

${ }^{29}$ Putra, 100.

${ }^{30}$ Ridwan, "Warga Kebomas Gresik Resahkan Pengajian MTA."
} 
nyata dari keteguhan mereka pada apa yang mereka yakini. Terlebih keteguhan pada idealis secara radikal tersebut berpotensi menjadi sebuah prilaku yang menolak bahkan menyalahkan segala konsensus yang ada dalam luar lingkaran mereka.

Namun, kelompok radikal seperti MTA yang ada di kabupaten Gresik tidak sampai berkembang secara pesat di masyarakat. Berbagai kelompok radikal yang pernah muncul di kabupaten Gresik hanya sebatas kelompok kecil yang tidak mampu melejit di masyarakat Gresik. Sehingga realita radikalisme di kabupaten Gresik hanya sebatas embrio-embrio kecil yang tidak dapat tumbuh secara baik di masyarakat. Hal ini terjadi karena iklim relegiusitas masyarakat Gresik yang cukup kental dan ditambah peran elemen-elemen pemerintah seperti Kementerian Agama Gresik yang secara sigap menyelesaikan fenomena radikalisme di masyarakat. ${ }^{31}$

\section{Upaya Menangkal Radikalisme}

\section{a. Pencegahan Radikalisme}

Berbagai upaya pencegahan radikalisme telah dilakukan Kementerian Agama Kabupaten Gresik melalui penyuluh agama yang berada disetiap wilayah kecamatan di Gresik. Secara struktural penyuluh agama yang berada di setiap kecamatan dinaungi langsung oleh Kantor Urusan Agama (KUA) yang berada di masing-masing kecamatan di Kabupaten Gresik. Sedangkan KUA sendiri dinaungi oleh Kantor Kementerian Agama Kabupaten Gresik. ${ }^{32}$ Sehingga melalui ketiga elemen tersebut secara struktural saling kordinasi untuk menciptakan berbagai upaya pencegahan radikalisme di setiap wilayah di Gresik.

Penyuluh agama selaku elemen yang secara langsung bersentuhan dengan masyarakat menjadikannya sebagai ujung tombak Kementerian Agama dalam menyelesaikan problem maupun membina berbagai hal yang terkait keagamaan. ${ }^{33}$ Penyuluh agama sebagai gerbang terdekat dengan masyarakat tentu mengemban tugas untuk melakukan berbagai kegiatan maupun penyuluhan agama sekaligus pembangunan melalui bahasa agama. ${ }^{34}$ Sehingga dapat dikatakan melalui penyuluh agama, Kementerian Agama Kabupaten Gresik berusaha melakukan bimbingan masyarakat mengenai keagamaan. Penyuluh agama menjadi elemen Kementerian Agama Kabupaten Gresik yang mengemban tugas pembimbingan keagamaan di masyarakat.

Adapun beberapa bentuk pembinaan yang dilakukan penyuluh agama di setiap wilayah kecamatan di kabupaten Gresik yakni seperti mengadakan kegiatan Majelis Ta'lim, pembinaan melalui Forum Komunikasi Diniyah Takmiliyah (FKDT), pembinaan juga dapat melalui Forum Komunikasi Pendidikan Al Qur'an (FKPQ), bahkan lebih dari pada itu dapat mengadakan kegiatan sosialisasi secara langsung di masyarakat. kegiatan sosialisasi yang diadakan penyuluh agama sendiri bermuatan mengenai bahayanya paham radikalisme, larangan paham radikalisme di Indonesia dan juga konsekuensi hukum bagi mereka yang melanggar larangan radikalisme. Sedangkan untuk intensifitas dari berbagai kegiatan tersebut yakni bersifat relatif. Ada yang dilaksanakan setiap hari, setiap minggu dan juga ada yang dilakukan secara kondisional tergantung situasi dan kondisi yang terjadi di internal maupun eksternal lembaga. ${ }^{35}$

\footnotetext{
${ }^{31}$ Munir, "Hasil Wawancara Dengan Kepala Sub Bagian Tata Usaha Kementerian Agama Kabupaten Gresik."

${ }^{32}$ Munir.

${ }^{33}$ Pajar Hatma Indra Jaya, "Revitalisasi Peran Penyuluh Agama Dalam Fungsinya Sebagai Konselor Dan Pendamping Masyarakat,” KONSELING RELIGI: Jurnal Bimbingan Konseling Islam 8, no. 2 (2017): 337.

34 “Keputusan Bersama Menteri Agama Republik Indonesia Dan Kepala Badan Kepegawaian Negara Tentang Petunjuk Pelaksanaan Jabatan Fungsional Penyuluh Agama Dan Angka Kreditnya,” Pub. L. No. 574 (1999), http://itjen.kemenag.go.id/sirandang/peraturan/3548-skb-574-1999-petunjuk-pelaksanaan-jabatan-funhsional-penyuluhagama-dan-angka-kreditnya.

${ }^{35}$ Munir, "Hasil Wawancara Dengan Kepala Sub Bagian Tata Usaha Kementerian Agama Kabupaten Gresik."
} 
Adapun berbagai upaya yang dilakukan oleh Kementerian Agama Kabupaten Gresik dalam pencegahan radikalisme termasuk dalam proporsi rasionalitas instrumental dalam sebuah konsep Tindakan Sosial Max Weber. Dapat dikatakan seperti itu, karena upaya-upaya pencegahan yang dilakukan oleh Kementerian Agama Kabupaten Gresik mengandalkan berbagai alat yang sebelumnya telah dimilikinya. Alat-alat tersebut diantara seperti pihak penyuluh agama, KUA, FKDT, FKPQ dan lain sebagainya. Berbagai pihak yang terkait tersebut secara tidak langsung menjadi alat struktural dari Kementerian Agama Kabupaten Gresik dalam upaya pencegahan radikalisme di Gresik. Melalui alat secara struktural tersebut diharapkan pembinaan keagamaan kepada masyarakat dapat berjalan dengan baik dan juga terstruktur secara rapi.

Melalui penyuluh agama maupun lembaga lain yang terkait ini juga dapat menjadi media efektif yang dilakukan oleh Kementerian Agama Kabupaten Gresik dalam pencegahan paham radikalisme di masyarakat Gresik. Begitulah kesadaran yang terbangun dalam rasionalitas Instrumental bagi Weber, dimana suatu individu atau kelompok akan mempertimbangkan tingkat efektifitas tindakan yang dilakukannya dalam mencapai suatu tujuan tertentu. Efektifitas dari penggunaan penyuluh agama sebagai tombak terdepan dalam pembimbingan keagamaan di masyarakat oleh Kementerian Agama Kabupaten Gresik yakni penyuluh agama merupakan pihak yang selain telah terlegitimasi profesi keagamaannya, juga penyuluh agama terdapat di setiap kecamatan di kabupaten Gresik. Sehingga melalui tersebarnya penyuluh agama di seluruh kecamatan di kabupaten Gresik ini maka dapat melancarkan kegiatan pemerataan pembinaan agama oleh Kementerian Agama Kabupaten Gresik secara menyeluruh di kabupaten Gresik.

\section{b. Penanganan Radikalisme}

Kunci dari iklim radikalisme di kabupaten Gresik yang hanya sebatas kelompok sosial berskala kecil atau tidak mampu sampai berkembang dengan pesat yakni integritas yang dimiliki pihak pemerintah dalam menangani fenomena radikalisme di kabupaten Gresik. Terutama pihak Kementerian Agama Kabupaten Gresik yang selalu sigap dalam menangani radikalisme di kabupaten Gresik. Disisi lain dalam penanganan radikalisme, Kementerian Agama Kabupaten Gresik juga bekerjasama dengan pihak-pihak tertentu seperti Pemerintah Daerah, Tim Kejaksaan, Badan Kesatuan Bangsa dan Politik (Bakesbangpol) dan juga Forum Kerukunan Umat Beragama (FKUB). ${ }^{36}$

Berbagai instrumen atau alat dalam bentuk kerjasama yang dilakukan Kementerian Agama Kabupaten Gresik ini menunjukkan bahwa integritas pihak pemerintah dalam menangkal radikalisme di kabupaten Gresik. Melalui kerja sama tersebut memperlihatkan bahwa kesungguhan dari pihak pemerintah dalam menangani radikalisme di kabupaten Gresik. Selain itu, melalui kerjasama dari berbagai elemen tersebut juga dapat menjadi instrumen pendukung Kementerian Agama Kabupaten Gresik dalam menangani radikalisme di kabupaten Gresik. Lebih dari pada itu bagi Weber, melalui rasionalitas instrumental yang dilakukan Kementerian Agama Kabupaten Gresik menunjukkan efektifitas suatu tindakan guna mencapai tujuan tertentu. Efektifitas instrumen yang digunakan dapat dilihat dari fungsinya masing-masing setiap elemen terkait. Maknanya setiap instrumen yang dimiliki dapat berperan aktif sesuai dengan fungsinya masing-masing, seperti dapat dilihat di FKUB yang berfungsi menjalin kerukunan di masyarakat.

Adapun beberapa langkah yang dilakukan Kementerian Agama Kabupaten Gresik dalam menangani munculnya kelompok yang diduga berpaham radikalisme yang ada di kabupaten Gresik. Langkah-langkah tersebut diantara sebagai berikut; ${ }^{37}$ Pertama, menggali informasi dari warga

\footnotetext{
${ }^{36}$ Munir.

${ }^{37}$ Munir.
} 
setempat mengenai kelompok yang diduga berpaham radikalisme. Kedua, mengklarifikasi pada pihak pemerintah setempat terkait kelompok yang diduga berpaham radikalisme. Jika memang keberadaan kelompok tersebut memang benar keberadaannya maka Kementerian Agama Kabupaten Gresik akan menemui secara langsung pada kelompok tersebut. Ketiga, Kementerian Agama Kabupaten Gresik melakukan komunikasi secara dialogis dengan kelompok yang bersangkutan. Dalam dialog tersebut Kemenag Gresik tidak serta merta menjustifikasi secara terburu-buru. Namun lebih tepatnya, dialog dihadirkan sebagai ruang klarifikasi, mendengar dan melihat secara langsung mengenai pola berfikir maupun pola tindakan yang dimiliki oleh kelompok yang bersangkutan.

Ketika dari dialog awal tidak ditemui indikasi yang mengarah pada radikalisme maka bahan pembicaraan yang ada di masyarakat hanyalah sebatas stigma belaka. Namun, ketika dari dialog tersebut ditemui indikasi yang mengarah pada radikalisme, maka Kementerian Agama Kabupaten Gresik akan langsung menindaklanjuti pada kelompok terkait. Tindak lanjut yang dilakukan Kementerian Agama Kabupaten Gresik yakni dengan cara menjalin komunikasi kembali pada kelompok terkait dengan kerjasama pada pihak-pihak tertentu. Dialog lanjutan ini sebagai bentuk pengarahan, pembimbingan, maupun pemberian nilai-nilai agama yang lebih moderat. Sehingga kelompok yang terindikasi radikalisme tersebut akan dibimbing oleh Kementerian Agama Kabupaten Gresik bersama pihak terkait guna mengubah cara berfikirnya yang lebih moderat, toleran dan juga menghindari prilaku ekstrem. Melalui tindakan tersebut mak kelompok-kelompok radikal yang masih berskala mikro tidak mampu berkembang secara pesat di kabupaten Gresik.

Jika ditelaah secara seksama, beberapa langkah tindakan yang dilakukan Kementerian Agama Kabupaten Gresik amat nampak berorientasi pada nilai-nilai tertentu seperti nilai moderat, nilai toleransi dan lain sebagainya. Terciptanya sikap moderat pada kelompok yang terindikasi radikal menjadi tujuan Kementerian Agama Kabupaten Gresik. Bagi Weber, tindakan tersebut merupakan rasionalitas nilai, yang mana suatu tindakan akan berorientasi pada nilai-nilai tertentu yang ingin dicapai. Begitupun yang terjadi dari berbagai langkah tindakan yang dilakukan Kementerian Agama Kabupaten Gresik dalam menangani kelompok radikal di kabupaten Gresik. Beberapa langkah yang dilakukan Kementerian Agama Kabupaten Gresik berorientasi menciptakan masyarakat yang lebih moderat, toleran, dan tentu saja terciptanya kerukunan di dalam masyarakat Gresik. Hal ini telah tertuang dengan rapi dalam visi yang dimiliki Kementerian Agama Kabupaten Gresik yakni "Terwujudnya masyarakat Gresik yang taat beragama, Inklusif, Toleran, Rukun, Berpendidikan, Mandiri, Sejahtera lahir batin." 38

\section{E. Kesimpulan dan Saran}

Iklim radikalisme di kabupaten Gresik tidak begitu populer dibandingkan di kota-kota besar lainnya yang hingga memunculkan tindak teorisme yang mengancam nyawa. Radikalisme di kabupaten Gresik masih sebatas embrio-embrio kecil dalam sebuah kelompok sosial mikro yang sebatas membid'ahkan golongan diluar kelompoknya seperti yang dilakukan MTA di kecamatan kebomas, Gresik. Namun, tindakan yang seperti itu tidak patut juga diremehkan begitu saja. Sebab, tindakan membid'ahkan orang lain dapat dikatakan cukup mengganggu stabilitas tatanan sosial di masyarakat. Lebih dari pada itu, dapat menimbulkan konflik antar kelompok di masyarakat.

Oleh karena itu, Kementerian Agama Kabupaten Gresik selaku pihak pemerintah yang bertugas dibidang keagamaan hadir sebagai media untuk menyelesaikan konflik tentang agama

\footnotetext{
${ }^{38}$ Fudlla, Profil Kantor Kementerian Agama Kabupaten Gresik Tahun 2019.
} 
yang timbul di masyarakat seperti radikalisme. Melalui tindakan rasionalitas instrumental Weber, Kementerian Agama Kabupaten Gresik menjalin kerjama dengan beberapa pihak, baik dari internal seperti KUA dan penyuluh agama maupun pihak eksternal seperti Pemerintah Daerah, Bakesbangpol dan lain-lainnya untuk menjadi instrumen atau alat khusus demi menangkal radikalisme di kabupaten Gresik. Berbagai upaya yang dilakukan Kementerian Agama Kabupaten Gresik bersama dengan beberapa instrumen yang dimiliki bertujuan untuk tercapainya nilai-nilai tertentu seperti toleran, moderat, dan rukun di masyarakat Gresik. Orientasi nilai atas suatu tindakan yang dilakukan tersebut sebagai bentuk nyata Kementerian Agama Kabupaten Gresik dalam rasionalitas nilai ala Weber yang dimilikinya.

\section{Daftar Pustaka}

Asrori, Ahmad. "Radikalisme Di Indonesia : Antara Historisitas Dan Antropisitas" 9 (n.d.): 253-68. Bungin, Burhan. Metodologi Penelitian: Format-Format Kuantitatif Dan Kualitatif. Surabaya: Airlangga University Press, 2005.

Fauzi, Muhamad Umar. "Strategi Penyuluh Agama Islam Dalam Menangkal Faham Radikalisme Di Kabupaten Nganjuk Muhamad Umar Fauzi." At-Tahdzib: Jurnal Studi Islam Dan Muamalah 6, no. 1 (2018): 17-49.

Fudlla. Kementerian Agama Kabupaten Gresik Dalam Angka 2019. Gresik: Humas Kantor Kementerian Agama Gresik, 2019.

- Profil Kantor Kementerian Agama Kabupaten Gresik Tahun 2019. Gresik: Humas Kantor Kementerian Agama Gresik, 2019.

Hekmatpour, Peyman. "What Do We Know about the Islamic Radicalism : A Meta-Analysis of Academic What Do We Know about the Islamic Radicalism : A Meta-Analysis of Academic Publications," no. January 2018 (2019).

Jaya, Pajar Hatma Indra. "Revitalisasi Peran Penyuluh Agama Dalam Fungsinya Sebagai Konselor Dan Pendamping Masyarakat.” KONSELING RELIGI: Jurnal Bimbingan Konseling Islam 8, no. 2 (2017): 335-56.

Keputusan Bersama Menteri Agama Republik Indonesia dan Kepala Badan Kepegawaian Negara tentang Petunjuk Pelaksanaan Jabatan Fungsional Penyuluh Agama dan Angka Kreditnya, Pub. L. No. 574 (1999). http://itjen.kemenag.go.id/sirandang/peraturan/3548-skb-574-1999petunjuk-pelaksanaan-jabatan-funhsional-penyuluh-agama-dan-angka-kreditnya.

Malthaner, Stefan. "Radicalization: The Evolution of an Analytical Paradigm." Archives Europeennes de Sociologie 58, no. 3 (2017): 369-401. https://doi.org/10.1017/S0003975617000182.

Masduqi, Irwan. BerIslam Secara Toleran: Teologi Kerukunan Umat Beragama. Bandung: Mizan, 2012.

Munir. "Hasil Wawancara Dengan Kepala Sub Bagian Tata Usaha Kementerian Agama Kabupaten Gresik." Gresik, 2020.

Putra, Muhammad Romdloni. "Islam Lokas Vis A Vis Islam Puritan (Studi Kasus Konflik Antara Majelis Tafsir Al-Qur'an Dan Nahdlatul Ulama Di Kabupaten Gresik).” Universitas Islam Negeri Sunan Ampel, 2018.

Ridwan, Mohammad. "Warga Kebomas Gresik Resahkan Pengajian MTA.” lensaindonesia.com, 2012. https://www.lensaindonesia.com/2012/12/06/warga-kebomas-gresik-resahkanpengajian-mta.html.

Sapta Ningsih, Windy. "Peran Penyuluh Agama Dalam Mengantisipasi Aliran Radikal (Studi Kasus KUA Kecamatan Metro Kibang Lampung Timur).” INSTITUT AGAMA ISLAM NEGERI METRO, 2019.

Siyoto, Sandu \& Ali Sodik. Dasar Metodologi Penelitian. Yogyakarta: Literasi Media Publishing, 2015.

Sukarelawati, Endang. "Pemkab Gresik Hentikan Kegiatan MTA.” jatim.antaranews.com, 2014. 
https://jatim.antaranews.com/berita/125601/pemkab-gresik-hentikan-kegiatan-mta.

Turner, Bryan S. Teori Sosial Dari Klasik Sampai Postmodern. Yogyakarta: Pustaka Pelajar, 2012.

Utami, Fajria Aninda. "Makam Sunan Giri Dan Sunan Gresik Sebagai Wisata Religi.” Umroh.com, 2020. https://umroh.com/blog/makam-sunan-giri-dan-sunan-gresik-di-gresik/.

Welianto, Ari. "Sunan Gresik, Wali Pertama Penyebar Islam Di Tanah Jawa." KOMPAS.com, 2020. https://www.kompas.com/skola/read/2020/02/22/120000769/sunan-gresik-wali-pertamapenyebar-islam-di-tanah-jawa?page=all.

Yunus, A Faiz. "Radikalisme, Liberalisme Dan Terorisme: Pengaruhnya Terhadap Agama Islam." Jurnal Online Studi Al-Qur An 13, no. 1 (2017): 76-94. https://doi.org/10.21009/jsq.013.1.06. 